\title{
AFFECTING PRICES OF INTANGIBLE ASSETS: \\ A PRELIMINARY TESTING \\ IN CONSUMER DURABLES SECTOR
}

\section{Pavel Svačina*}

\begin{abstract}
:
In the last few decades, a valuation of intangible assets is an activity of particular importance, not only because of growing number of transactions with intangibles but for accurate financial reporting as well. In this discipline, a special area is dedicated to the research of different factors that affect the value of intangibles. Royalty rate, a price of the licensed intangible, is a typical measure of an intangible asset's value. This research paper aims at testing empirically selected factors that have been identified by theoretical literature as well as by licensing practice as relevant in determining the level of royalty rates. For this purpose, a multi-factor linear regression model is built using the latest possible sample of licensing transactions from consumer durables industry from 2002 to 2006. The authors make tests of dependent variable (royalty rate) on financial factors as well as on factors coming from different provisions of licensing agreements. Based on a sample of 67 transactions, the financial factors revealed themselves to be statistically negligible, while some license provisions, in particular the extent of rights granted and the license term appeared to be highly significant in determining the royalty rate level.
\end{abstract}

Keywords: intangible assets, intellectual property rights, licensing, valuation, valuation approach, royalty rates, value factors, empirical study

JEL Classification: D45, G12, G32, L24, O34

\section{Introduction}

In the last few decades, intangible assets such as patents, trademarks, software, trade secrets, utility models, industrial designs and copyrights, commonly called intellectual property rights, have become of a noticeable importance in the global marketplace. One of the main reasons of this phenomenon lies in a growing global competition that forces companies and individuals to look for solid competitive advantages. Investments into intangible assets (e.g. strong brand name) could be the source of such an advantage (Lev, 2001). Continuous process of intellectual property rights enforcement, driven by multilateral international agreements as well as by the EU and national laws, made easy for intellectual properties to become an object of an exchange similar to tangible assets (real estate or machinery). Such an exchange can have a form of a licensing transaction or rights assignment between unrelated or related entities (see the OECD transfer-pricing guidelines), business combinations reported for IFRS or US GAAP standards, capital

* Pavel Svačina, University of Economics in Prague, Prague, Czech Republic (svacina@vse.cz).

This study was supported by the Research Project of the Faculty of Finance and Accounting of the University of Economics in Prague (No. VSE IP 100040). 
contributions into new companies, litigations, etc. (Svačina, 2010). Since 2000, the professional appraisers have been challenged by some important changes. One of them happened when OECD transfer-pricing guidelines were actualized and deepened, another was caused by adoption of a new US GAAP and IFRS standards for business combinations. These new rules for financial reporting command, among others, to estimate the fair value of all intangible assets of the acquired company, no matter if previously reported or not in the balance sheet. Such rules enabled the progress in the development of valuation methods for quite specific intangibles, such as customer relationships or assembled workforce. The valuation of intangible assets is a relatively difficult discipline as one needs to understand specific factors and risks that affect the value of an intangible asset and, in general, to have a set of interconnected economic, legal and technical knowledge. An income approach is the one frequently used for intangible asset's market value estimate. For this approach, the structure of a licensing agreement is basic, because the licensing agreement is a typical legal form of market exchange for intellectual properties. In the licensing transaction, the licensee pays a royalty rate to the licensor as the price for a certain package of exchanged rights for the use of that intangible. The royalty rate is calculated mostly as a percentage of the licensee's sales. The value of an intangible asset is therefore calculated as a present value of all royalty payments that flow or would flow to the intangible asset's owner from the use of that asset. In the licensing negotiations, many factors affect the final royalty rate estimate. The most relevant of these factors should be taken into account by professional appraisers when valuing a similar intangible asset for different purposes mentioned above.

This paper aims at testing empirically selected factors that affect the level of royalty rates identified by theoretical literature and used in practical licensing. The result should serve the community of professional appraisers to better identify relevant value factors as well as to consider better the influence of such factors on the intangible assets' value.

\section{Factors Affecting Royalty Rates}

Since 1980 there has been a discussion about factors affecting the level of royalty rates. The first and big milestone has been put in the late seventies/early eighties during the famous patent litigation case Georgia-Pacific Corporation vs. United States Plywood Corporation where the judge together with various economic and law experts defined fifteen basic factors that should be considered for the patent infringement damage estimate. ${ }^{2}$ These factors are:

(i) royalties received by licensor for licensing the patent, proving or tending to prove an established royalty,

(ii) rates paid by the licensee for the use of similar patents,

(iii) nature and scope of the license,

(iv) policy of maintaining patent monopoly,

(v) commercial relationship between licensor and licensee,

(vi) patent effect on "convoyed" sales,

(vii) duration of the patent and the term of the license,

(viii) profitability of the patented product, its commercial success and popularity,

2 Georgia-Pacific Corp. v. United States Plywood Corp., 318 FSupp 1116, 6 USPQ 235 (SD NY 1970). 
(ix) utility and advantages of the patent over any old modes or devices,

(x) commercial embodiment of patent,

(xi) extent to which the infringer used the invention,

(xii) portion of the profit or selling price that is customary in the particular business,

(xiii) portion of profit that should be credited to the invention compared to non-patented elements,

(xiv) opinion testimony of qualified experts,

(xv) amount that licensor and a licensee would have agreed upon at the time the infringement began if they had reasonably and voluntarily tried to reach an agreement.

These factors are in many variations cited in the following theoretical foreign and domestic literature dedicated to intangible assets' valuation (Razgaitis (1999), Smith (2000), Svačina (2010)) and are in some way used in professional valuation reports.

\section{State of the Art}

The state of the art of the literature focused on the intangible assets' value factors that could be divided into four research directions. The first direction could be called "descriptive" and focuses on the identification of relevant factors. This type of research is done mostly by questionnaire surveys. Among the most complex, we can make a reference to McGavock et al. (1992), Park and Park (2004) and Chiesa et al. (2007). By questioning licensing managers, McGavock et al. (1992) find the most relevant factors (i) legal protection strengths, (ii) utility of the intangible, (iii) product profitability, (iv) exclusivity of rights granted, and (v) license duration. Park and Park (2004) find intrinsic factors (i-iv) and application factors (v-viii): (i) degree of protection, (ii) level of technology, (iii) life of technology, (iv) degree of standardization and interoperability of technology, (v) type of technology (product, process or material), (vi) contribution ratio of subject technology to total value, (vii) scope of application (fields to be marketed or applied) and (viii) degree of completeness. Chiesa et al. (2007) define broad five areas with systematically identified factors within each of these areas: (i) asset related factors, (ii) firm related factors, (iii) context related factors, (iv) risk related factors, and (v) transaction related factors. However, Chiesa et al. (2007) include basically all factors of previous authors, adding a logical structure and redefining some of them. The second research direction, let us call it "simple empirical", aims at collecting and simple empirical testing of factors defined by previous literature. Methodically, these authors apply elementary statistical instruments like frequency charts, means etc. Within this area, we can refer to the newest research of the Licensing Executive Society, carried out in the USA and Canada (LES, 2012). The major part of the LES study contains the frequency charts and other simple descriptive methods in hi-tech industries for the following factors: technology phase, motives of transaction partners, type of organization, size of licensor and licensee, type of asset, field of use, degree of exclusivity, existence and level of down payment. The third research direction, called here as "individual factor testing" heads to deeper analyses of individual value factors. A part of McGavock et al. (1992) study analyses the royalty rates from the perspective of technology uniqueness factor, using comparisons of averages or medians. Identifying three classes for the degree of technology uniqueness, they found the same class technologies from the pharmacy systematically higher then technologies outside the pharmacy. Varner (2010) analyses the factor of legal protection (patent, know-how, 
combination) in the hi-tech sectors. Comparing the samples with different type of legal protection, he founds royalties in patent transaction on average higher than royalties in know-how transactions. A particular attention is paid to the profitability factor. In the licensing sector, a non-written rule ( 25 per cent rule) says that a licensor takes from one fourth up to one third of the profit from the licensee, putting into strong relation royalty rates and licensee's product profitability. Goldscheider (2002) proposes the first empirical research on this topic, putting together a broad sample of net sales royalty rates from various industries and operating profit margins of relevant licensees. He found the 25 per cent rule relevant and identified consequently the licensee's profitability as an important factor. The fourth research direction, called here as "sophisticated empirical" uses more sophisticated statistical methods, especially multi-factor regressions. Our paper could be put into this category. Kemmerer and $\mathrm{Lu}$ (2008) and $\mathrm{Lu}$ (2011a) analyses industry royalty rates with the mean values of relevant industry profit margins. He argues for the Goldscheider's (2002) opinion about strong relationship between royalty rates and profitability factor. Kidder and O'Brien (2011) or Jarczyk (2011) sharply argue against these results taking into account quite unclear definition of profitability and negligible statistical significance of previous studies. Goldscheider (2012) makes a compromise and explains the 25 per cent rule and consequent profitability factor as a good starting point in licensing negotiations, but puts a strong significance also to the other Georgia-Pacific factors that we describe above. Lu (2011b) finds a significant statistical correlation between industry royalty rates and combination of Tobins's Q (market to replacement value of companies) and book value of intangibles reported in balance sheets for relevant industries. Other research papers focus on testing the relationship between values of intangibles and patent claims or citations, Trajtenberg (1990) among others. Allison et al. (2003) compare the sample of litigated patents with another sample of non-litigated patents. Based on the assumption that litigated patents have the highest value, they identify the several attributes unique for litigated patents - they are relatively newly granted, owned mostly by U.S. companies, granted to the individuals more than to companies, longer patent prosecution, more patent claims and granted for specific industries (mechanics, computers, medical devices). The most complex multi-factor empirical testing seems to be offered by Sakakibara (2010) who analyses 661 Japanese patent transactions from 1998-2003. She tests the following factors: type of organization of licensor/licensee, number of patent applications before the effective date of transaction (1998-2002), size of licensor/licensee, industry, proximity of a licensed patent to a licensor's core technology, patent effectiveness, technology category, time gap between the date of application and effective date of license, exclusivity and scope of patent. The author analyses separately the transactions paid by lump-sum and by running royalties and uses a linear multi-factor regression model with linear transformation. The conclusions are as follows: a) much better dependent variable is the running royalty rather than the lump-sum payment, b) significant factors are the patent effectiveness (how much a patent protects the competing advantage) and the relative bargaining power of licensor and licensee.

\section{Objectives of the Study}

The papers referred above offer various methodologies for identifying and measuring the significance of factors affecting the value of intangibles. Mostly, they analyse patent 
and know-how transactions. While the theoretical and practical identification of factors is practically done and there is a general consensus about the identification of relevant value factors, the empirical knowledge of the relative significance of these factors is quite fragmented. Fragmented is also the definition of particular factors in individual papers. Moreover, some of significant empirical results lack direct consequences to the practice, because many factors have a complicated definition, despite the fact they are proved statistically (e.g. patent effectiveness, see above). In general, a simple and comprehensible empirical research about relative importance of value factors is missing.

The objectives of this paper is to make this type of research, the more, in a way that is easy to understand for real practitioners. We choose relevant available value factors that could be effectively used in the professional valuation process. We also use quite simple linear regression model with several variables. Other than non-linear relationships are not suitable for practical use. We analyse a sample of real licensing agreements as we consider royalty rates the most objective and available expression of an intangible asset's price. Our sample differs from previous studies especially by the various intangible asset types included (not only patent or know-how). In particular, we test the following hypotheses:

H1: Financial factors reported for the licensees' companies affect significantly the level of royalty rates.

H2: License agreement provisions affect significantly the level of royalty rates.

\section{Methods}

To find key factors affecting royalty rates, we used a multi-factor linear regression model (comp. Sakakibara, 2010) in the following form:

$$
Y_{i}=\beta_{0}+\beta_{1} x_{i 1}+\beta_{2} x_{i 2}+\ldots+\beta_{m} x_{i m}+\varepsilon_{i},
$$

where: $Y$ - sales royalty rate as predicted (dependent) variable,

$x$ - theory-based value factors as explanatory (independent) variables,

$\beta$ - regression coefficients showing the degree and direction of dependence,

$j$ - number of explanatory variables, $j=1, \ldots, m$,

$i$ - number of observation (transactions), $i=1, \ldots, n$,

$\varepsilon$ - error term.

The main reason for using a linear regression is to be as clear as possible in terms of practical use of our results. After all, our preliminary analyses did not show better results for non-linear models. Further, we made a linear data transformation because both royalty rates and the majority of value factors showed a log-normal distribution. For that we used a natural logarithms. We selected the following set of available and theory-based value factors as explanatory variables: R\&D Expenditures, Assets, EBIT/Sales, R\&D/Sales, Effective Date of license (Year), Agreement Type (number of rights granted), Territory (GDP), Exclusivity, Term (length of contract in years). Financial factors come from the licensees' financial statements and we defined them as $3 \mathrm{Y}$ averages based on ex-post data, beginning with the next year after the effective date of transaction. The licensing provision factors are defined as follows: Agreement Type is the number of rights connected with the individual transaction defined in the ktMine database (e.g. marketing 
or cross license), Territory is represented by the nominal GDP of licensed territories in 2010, Exclusivity is a binary value on the scale exclusive/non-exclusive, Term is the basic license period written in the agreement, without options for prolongation. The selection of the value factors is based on the following:

- all of them are theory-based as well as practice-based, as referred in previous chapters,

- not all possible factors discussed in theory and practice are tested in our paper, as we aim at testing first the factors that are both discussed the most and are useful for professional valuations (licensing provisions, licensees' financials),

- $\quad$ our analysis has a preliminary character - the results should serve as a starting point for other broader research.

\section{Sample/Data}

We analysed $n=67$ licensing agreements from ktMine royalty rates database, financials come from Capital IQ database, calculations are made in the Statgraphics Centurion XVI. Our sample has the following characteristics:

- $\quad$ transactions with effective date between 2002-2006,

- $\quad$ net and gross sales agreements with positive royalty rates,

- $\quad$ agreements with clear effective date (year),

- transactions where at least one type of relevant financial information for licensee was available,

- intangible asset classified by ktMine to the consumer durables sector,

- $\quad$ transactions classified to the marketing intangible ${ }^{3}$ (there are also some patents, software and other assets are included, otherwise the sample would be too narrow).

See the Table 1 for data summary statistics.

Minimum observed royalty rate is 0.0025 . Factor Agreement type has a range from 1 to 4 (e.g. 1 = Marketing Transaction, 2 = Marketing and Manufacturing Transaction, 3 = Asset Purchase, Manufacturing and Marketing, 4 = Cross License, Manufacturing, Marketing, Software). Factor Effective date has the following counts between 2002-2006: $6,21,14,21,5$. The count of exclusivity transactions is 61 , non-exclusive 3 . The maximum 30 in factor Term are licenses with indefinite duration.

3 License is likely to grant the right to use any of the following: trademarks, trade names, trade dress, copyrights, service marks, logos. 


\begin{tabular}{|l|r|r|r|r|r|}
\hline & Count & Average & $\begin{array}{r}\text { Standard } \\
\text { deviation }\end{array}$ & Minimum & Maximum \\
\hline Royalty rate (\%) & 67 & 0.16 & 0.19 & 0.00 & 1.00 \\
\hline Agreement type & 67 & - & - & 1.00 & 4.00 \\
\hline Effective date (year) & 67 & - & - & 2002 & 2006 \\
\hline $\begin{array}{l}\text { Exclusivity (0-nonexlusive; } \\
\text { 1-exclusive) }\end{array}$ & 64 & - & - & 0 & 1 \\
\hline Territory (GDP 2010, bil. USD) & 55 & $42,463.00$ & $24,119.60$ & $1,413.76$ & $63,226.40$ \\
\hline Term (years) & 47 & 6.43 & 7.30 & 0.70 & 30.00 \\
\hline R\&D Exp. (mil. USD) & 67 & 76.23 & 279.41 & 0.00 & $1,173.67$ \\
\hline Assets (mil. USD) & 67 & $4,620.76$ & $25,336.30$ & 0.00 & $203,574.00$ \\
\hline EBIT/Sales (ratio) & 59 & -59.22 & 239.18 & $-1,304.44$ & 0.39 \\
\hline R\&D/Sales (ratio) & 60 & 1.70 & 8.24 & 0.00 & 61.15 \\
\hline
\end{tabular}

\section{Results and Discussion}

We tested selected value factors at the 0.05 significance level. Given the defined sample of transactions and selected linear model, the results show that some relevant theory-based value factors are significant also empirically. At chosen significant level, we found two significant explanatory value factors: Agreement Type and Term. The model explains 36.41 per cent of the variability in observed royalty rates. Both P-value for the whole model and P-values for value factors are below chosen significant level (AgrType: $\mathrm{P}=0.03$, st. error $=0.26$; Term: $\mathrm{P}=0.00$, st. error $=0.15$ ), which is significant for explaining royalty rates level. Estimated model $(\mathrm{P}=0.00)$ has the following form: ${ }^{4}$

$$
\log (\text { Value })=-1.64+0.59 \times \log (\text { AgrType })-0.66 \times \log (\text { Term }) .
$$

The equation says that the royalty rate for an intangible asset is most sensitive generally on combination of traded license rights package and the duration of the license. It is a bit surprising that both relevant factors are the provisions from analysed license agreements. By contrast, no financial factor from licensees' companies appeared to be significant, no matter whether in nominal or relative form. Both significant factors, agreement type and term, show logical correlations - agreement type is positively correlated to the royalty rate because the more rights granted the higher the royalty rate; license term is negatively correlated because the longer the duration of license, the lower the pressure of licensor on the royalty, as he gets more money due to the longer period. Our model has $\mathrm{R}^{2}=36.41$ per cent $\left(\mathrm{R}^{2}\right.$ adj. $=33.15$ per cent $)$. Generally, $\mathrm{R}^{2}$ around 30 per cent is quite low statistical result, however, in the context of intangible assets it is

4 We also made a diagnostics tests on multicollinearity, analysis of residuals and influential points.

Also from this perspective the model is acceptable. 
a noticeable finding - it is three times higher than $\mathrm{R}^{2}$ of Sakakibara (2010) who analyses different value factors on patent transactions by similar methods. Given these results, we can respond our hypotheses:

H1: Based on our data sample and analysis we reject the hypothesis that licensees' financial factors are significant factors for determining the level of royalty rates.

H2: By contrast, we do accept the hypothesis that selected provisions of license agreements are factors significant for determining the level of royalty rates.

Our results partly conform to the assumptions of the theory which considers both scope of granted rights and license period as relevant factors affecting the price of an intangible. Our results show explicitly and empirically different factors that has been published in previous literature (especially Sakakibara, 2010) but is not in contradiction with them. Other studies used different samples (mostly patent and know-how transactions) and different explanatory factors. On the other hand, the insignificant relationship between royalty rates and financial factors is quite surprising. Such results complicates an easy use of the 25 per cent rule for valuation of intangibles (comp. Goldscheider, 2002). Based on our results, many professionals should reconsider the easy use of licensee's profit margin as a key driver for estimating the royalty rate, because the profit margin as a factor seems overestimated. Nevertheless, we need a deeper research in this area.

\section{Limitations}

We used a sample of 67 transactions from 2002 to 2006. Data are from the relatively broad consumer durables sector. Sample size from one industry is limited by the relatively weak liquidity in intangibles sector, as well as by the availability of financials from licensing companies. We did not count transactions without financials available or without transparent effective date. The data include various types of marketing intangible assets, various licensors and licensees (inventors, universities or commercial companies). We found significant value factors the agreement type and license term. While the license term we took as a basic period from the agreement, the agreement type is a number of rights attributed the particular agreement by ktMine database. Further research can be done with more precise definition of the agreement type factor as well as with considering options for license prolongation. As for the provisions of license agreements, one of the most theory-based factor is the exclusivity, with a positive correlation to the level of royalty rate. We had just three non-exclusive agreements, so we could not analyse this factor and consequently we cannot say anything about his empirical influence. A certain limit is also a five-year data sample - on the one hand, such a sample is based on the newest available data, on the other hand it does not allow to analyse the time trend. We did not use transactions after 2006 due to the lack of consistent financial data set available for licensees after 2006. As the part of the financial data comes from 2007 to 2009, such sample could be biased by coming economic crisis and volatile financial results of licensees. Moreover, some of the licensees were newly established companies, whose financial results may not be completely representative. Regardless of these limitations, the findings are consistent with the theoretic literature and it will be interesting to see a broader and deeper research with a bigger data sample. 


\section{Practical Implications and Conclusion}

By our research, we aimed at getting some solid foundations for better identification and considering various value factors for professional valuations of intangible assets. By our approach we proved easy and consequently well utilizable relationship between the royalty rates and scope of granted rights and license period (similar to the asset's economic life). The first factor with positive, the second with negative correlation. We built a linear model with $\mathrm{R}^{2}$ above 30 per cent, which is highly above average within the field on intangibles. Our results can be used as a support study for intangible assets valuations in the way that both significant value factors should be at least considered and discussed in a particular valuation case. This is not always the case in the valuation practice. Another practical implication of our study is the opinion on the profitability factor. Based on our results, we cannot consider the profitability as well as other financial factors to be very significant value factors for the royalty rate estimate. More likely, financial factors can be used as a helping starting point in setting the royalty rates. Nevertheless, stronger opinions should be supported by further research on a broader data sample and variant definition of the profitability factor.

\section{References}

Allison, J. R., Lemley, M. A., Moore, K. A., Trunkey, R. D. (2003), "Valuable Patents.” University of California at Bekeley, Shool of Law, Public Law and Legal Theory Research Paper Series No. 133.

BVLibrary (2013), “Georgia-Pacific Corp. v. United States Plywood Corp., 318 FSupp 1116, 6 USPQ 235 (SD NY 1970)", a court-case available at BVLibrary: http://www.bvlibrary.com/ pdf/files/courtcase/5368.pdf

Chiesa, V., Frattini, F., Gilardoni, E., Manzini, R., Pizzurno, E. (2007), "Searching for Factors Influencing Technological Asset Value." European Journal of Innovation Management, Vol. 10, No.4, pp. 467-488.

Goldscheider, R. (2012), "The Current Realities of the Classic 25\% Rule: An Attempt to Put the House in Order." Les Nouvelles, Vol. XLVII, No. 1, pp. 1-7.

Jarczyk, D. (2011), “Replacing the 25 Percent Rule with Fact-Based Evidence-A Guide To Finding and Analyzing Royalty Rates." Les Nouvelles, Vol. XLVI, No. 4, pp. 279-282.

Kemmerer, J. E., Lu, J., (2008), "Profitability and Royalty Rates across Industries: Some Preliminary Evidence." KPMG Global Valuation Institute, SSRN Working Paper.

Kidder, D. G., O’Brien, V. E. (2011), “Simply Wrong: the 25\% Rule Examined." Les Nouvelles, Vol. XLVI, No. 4, pp. 263-268.

Lev, B. (2001), Intangibles: Management, Measurement and Reporting. Washington, D.C., Brookings Institution Press.

Licensing Executive Society (LES, 2012), 2011 High Technology Sector Deal Term \& Royalty Rate Survey Report. A Survey Available for LES Members at www.lesi.org.

Lu, J. (2011a), "The 25\% Rule Still Rules: New Evidence from Pro Forma Analysis in Royalty Rates." Les Nouvelles, Vol. XLVI, No. 1, pp. 14-17.

Lu, J. (2011b), "Intangible Assets Valuation by License Market and Stock Market: Cross-Industry Analysis Based on Royalty Rate and Tobin's Q." Les Nouvelles, Vol. XLVI, No. 2, pp. 100-114. 
McGavock, D. M., Haas, D. A., Patin, M. P. (1992), “Factors Affection Royalty Rates.” Les Nouvelles, Vol. XXVII, No. 2, pp. 107-116.

OECD (2013), Main Economic Indicators. Volume 2013/4, Paris: Organization for Economic Cooperation and Development.

Park, Y., Park, G. (2004), "A New Method for Technology Valuation in Monetary Value: Procedure and Application." Technovation, Vol. 24, pp. 387-94.

Razgaitis, R. (1999), Early-Stage Technologies: Valuation and Pricing. Hoboken, NJ: John Wiley\&Sons. Inc.

Sakakibara, M. (2010), "An Empirical Analysis of Pricing in Patent Licensing Contracts." Industrial and Corporate Change, Vol. 19, No. 3, pp. 927-945.

Smith, G., Parr, R. (2000), Valuation of Intellectual Property and Intangible Assets, 3rd Ed. Hoboken, NJ: John Wiley\&Sons. Inc.

Svačina, P. (2010), Oceňování nehmotných aktiv, 1st Ed. Prague: Ekopress.

Trajtenberg, M. (1990), "A Penny for Your Quotes: Patent Citations and the Value of Innovations." The RAND Journal of Economics, Vol. 21, No. 1, pp. 172-187. 